\title{
Fumigant toxicity and antiacetylcholinesterase activity of Saudi Mentha longifolia and Lavandula dentata Species against Callosobruchus maculatus (F.) (Coleoptera: Bruchidae)
}

Suudi Mentha longifolio ve Lavandula dentata türlerinin Callosobruchus maculatus (F.) (Coleoptera: Bruchidae)'a karşi fümigant toksisite ve antiasetilkolinesteraz etkinliği

\author{
Ali S. AL-SARAR ${ }^{1^{*}}$ Hamdy I. HUSSEIN ${ }^{1} \quad$ Yasser ABOBAKR $^{1}$ \\ Alaa E. BAYOUMI ${ }^{1} \quad$ Mubarak T. AL-OTAIBI $^{1}$
}

\begin{abstract}
Summary
Mentha longifolia (L.) and Lavandula dentata (L.) (Lamiaceae) are two wild growing folk medicine plants that in Saudi Arabia. This work was conducted to investigate the chemical composition and evaluate the fumigant toxicity of their essential oils against the adults (3-5-day-old) of cowpea beetle, Callosobruchus maculatus (F.) (Coleoptera: Bruchidae). The main compounds in $M$. longifolia oil were pulegone $(74.95 \%), 1,8$-cineole $(7.35 \%)$, I-menthone $(6.62 \%)$, and eucarvone $(2.68 \%)$, while the main constituents in L. dentata oil were camphor $(61.43 \%)$, fenchone (24.3\%), d-fenchol (2.15\%), and linalool (1.52\%). The two oils showed LC $_{50}$ values of 4.43 and $7.92 \mu \mathrm{L} / \mathrm{L}$ air and exhibited antiacetylcholinesterase activity with IC50 values of 1.01 and $9.74 \mu \mathrm{l} / \mathrm{ml}$, respectively. The results proved the potential use of these natural materials as effective alternatives to synthetic pesticides.
\end{abstract}

Key words: Fumigant toxicity, essential oils, acetylcholinesterase, Mentha longifolia, Lavandula dentate, Callosobruchus maculates

\section{Özet}

Mentha longifolia (L.) ve Lavandula dentata (L.) (Lamiaceae) Suudi Arabistan'da bulunan iki yabani akraba tıbbi bitkidir. Bu çalışma, bu bitkilerin kimyasal bileşimini araştırmak ve depolanan bakliyatın önemli bir zararlısı olan börülce tohum böceği [Callosobruchus maculatus (F) (Coleoptera: Bruchidae)] erginine (3-5-gün yaşında) karşı esansiyel yağların fümigant toksisitesini değerlendirmek için yapılmıştır. $M$. Iongifolia yağı içinde ana bileşikler, pulegon (\% 74,95), 1,8-cineole (\% 7.35), I-menton (\% 6.62) ve eucarvone (\% 2.68) iken $L$. dentata'da ana bileşenler ise kamfor (\% 61.43), fenkon (\% 24.3), d-fenkol (\% 2.15) ve linalool (\% 1.52)'dur. İki yağ sırasıyla 4,43 ve $7.92 \mu \mathrm{Ll} / \mathrm{L}$ hava $L_{50}$ ve, 1,007 ve $9,74 \mu \mathrm{l} / \mathrm{ml}$ IC50 değerleri ile antiasetilkolinesteraz aktivitesi göstermiştir. Sonuçlar bu doğal materyallerin tehlikeli sentetik pestisitlerin yerine etkili alternatif olarak potansiyel kullanımın kanıtlamıştır. Esansiyel yağların geleneksel pestisitlere göre avantajlari ortaya konmuştur.

Anahtar sözcükler: Fumigant toksisite, esansiyel yağlar, asetilkolinesteraz, Mentha longifolia, Lavandula dentate, Callosobruchus maculates

\footnotetext{
1 Plant Protection Department, College of Food and Agriculture Sciences, King Saud University, P.O. Box 2460, Riyadh 11451, Saudi Arabia.

* Corresponding author; e-mail: asarar@ksu.edu.sa

Alını̧ (Received): 14.05.2013 Kabul ediliş (Accepted): 08.11.2013
} 


\section{Introduction}

Mentha longifolia (L.) and Lavandula dentata (L.) (Lamiaceae) are two widespread herbs that grow wild in Saudi Arabia as well as in many other countries around the world. These plants have many uses in folk medicine (Mossa et al., 2001; Asekun et al., 2007). It was reported that the two plants have insecticidal (Odeyemi et al., 2008; Koliopoulos et al., 2010) and antimicrobial activities (Imelouane et al., 2009; Hafedh et al., 2010; Hussain et al., 2010). The constituents of essential oils of the same plant species differ qualitatively and quantitatively according to the environmental conditions and to the method the plant is manipulated: fresh, air-dried, oven-dried, etc. (Asekun et al., 2007; Ross \& Sombrero, 1991; Singh et al., 2008). Many targets, including acetylcholinesterase and octopaminic systems, have been proposed as the cause of killing insects exposed to fumigation with essential oils (Kostyukovsky et al., 2002; Enan, 2005a,b; Orhan et al., 2008; López \& Pascual-Villalobos, 2010; Şenol et al., 2010). The cowpea beetle, Callosobruchus maculatus (F.) (Coleoptera: Bruchidae) is an important pest that causes great damage to cowpea and other stored pulses (Casswell, 1988; Dongre et al., 1993). Many reports have been published on the insecticidal activity of essential oils against $C$. maculates (Negahban et al., 2007; Lolestani \& Shayesteh, 2009; Aziz \& Abbass, 2010; Hashemi \& Safavi, 2012). Therefore, this work was carried out to examine the chemical composition of essential oils isolated from $M$. longifolia and $L$. dentata species grown in Saudi Arabia and to evaluate their fumigant toxicity and anticholinesterase activity against adult $C$. maculatus, to compare the composition of the two plant oils grown in other countries. This work is a continuation to our efforts to find promising, effective natural pesticides (Hussein et al., 1994, 1999; Al-Rajhi et al., 2003; Hussein, 2005; Al-Sarar et al., 2012).

\section{Materials and Methods}

\section{Plant samples}

Samples of $L$. dentata were collected from Asir region in February, 2010, while samples of $M$. longifolia were purchased from a local supermarket in March, 2010. The plants were identified by the Botany Department, King Saud University.

\section{Isolation of essential oils}

Fresh leaves of $M$. longifolia and fresh leaves and flowers of $L$. dentata were macerated with distilled water and subjected to solvent steam distillation for $3 \mathrm{~h}$. Distillates were extracted with diethylether (BDH, England); extracts were dried with anhydrous sodium sulphate (BDH, England), and then solvent was evaporated under vacuum, using rotary evaporator (Rotavapor R-215, Germany) with V855 vacuum controller. Oils were kept at $-20^{\circ} \mathrm{C}$ in glass vials with Teflon screw caps.

\section{Instrumental analysis}

Agilant Technologies $6890 \mathrm{~N}$ Network system equipped with Agilant 7683 automatic injector and Agilant 5973 mass selective detector was used for MS identification of the components. Agilant DB- 35 MS (30 m, $0.25 \mathrm{~mm}$ i.d and $0.25 \mu \mathrm{m}$ film thickness) capillary column was used with the following oven temperature programme: initial temperature $40^{\circ} \mathrm{C}, 2^{\circ} \mathrm{C} / \mathrm{min}$ ramp to $200^{\circ} \mathrm{C}$, held for $5 \mathrm{~min}$, pressure 7.5 psi. The flow rate of carrier gas (helium) was in constant flow mode at $1 \mathrm{ml} / \mathrm{min}$; splitless injection of $1 \mu \mathrm{l}$ oil sample, dissolved in methanol, was carried out at $200{ }^{\circ} \mathrm{C}$; the mass spectrometer was operated in electron ionization mode with a transfer line temperature at $280^{\circ} \mathrm{C}$. Compounds were identified using Wiley 7 data bases.

\section{Insecticidal activity}

\section{Test insects}

Callosobruchus maculatus adults, reared in the insectary of Plant Protection Department at $28 \pm 11^{\circ} \mathrm{C}$ and ambient $40-70 \% \mathrm{RH}$, were allowed to lay eggs on kidney bean seeds. Emerged adults (3-5-day-old) were used for fumigant toxicity study. 


\section{Fumigant toxicity trials}

Adults (mixed sex) were introduced into $250 \mathrm{ml}$ glass bottles; the oil volume required to achieve the aimed concentration (3-24 $\mathrm{\mu l} / \mathrm{L}$ ) was introduced into $3 \mathrm{ml}$ glass vials with the aid of Eppendorf micropipette; vials openings were secured with cloth netting and hanged inside the glass bottles with the aid of a string, and caps were screwed tightly with an extension of the string outside the bottle opening (Figure 1). Three replicates were used for each concentration, 20 insects for each replicate. Dead insects were detected $48 \mathrm{~h}$ after treatment by not responding to probing with a pin.

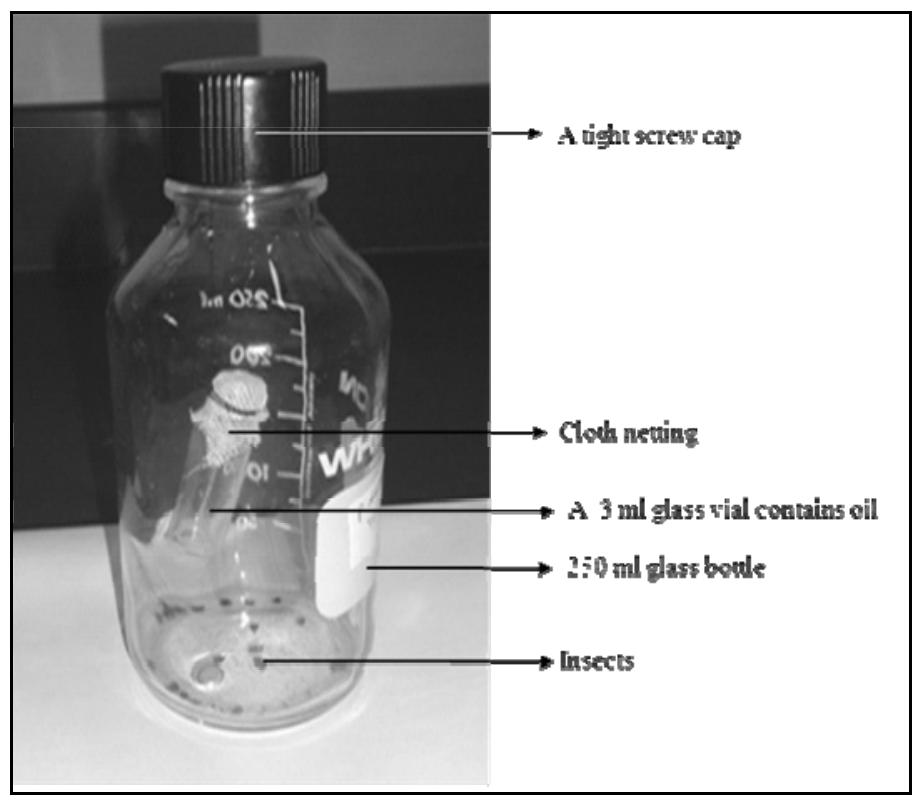

Figure 1. A simple method to fumigate insects with essential oils.

\section{Antiacetylcholinesterase activity}

\section{Isolation of acetylcholinesterase}

Whole adults $(0.5 \mathrm{gm})$ were homogenized with $5 \mathrm{ml}$ phosphate buffer $(\mathrm{pH} 8)$, using Ultra-Turax $\mathrm{T}$ 25, IKA homogenizer; and then the homogenate was centrifuged at $1000 \mathrm{rpm}$ for $3 \mathrm{~min}$. The supernatant was centrifuged at $5000 \mathrm{rpm}$ for $5 \mathrm{~min}$ and the supernatant was used as crude acetylcholinesterase.

\section{Determination of anticholinesterase activity}

Anticholinesterase activity was determined according to the method of Ellman et al. (1961). In brief, in case of control treatment, $2.8 \mathrm{ml}$ phosphate buffer $(\mathrm{pH}$ 8), including the volume of ethanol found in treatment samples, $100 \mu \mathrm{LTNB}(0.01 \mathrm{M})$, and $100 \mu \mathrm{l}$ enzyme solution were added into $15 \mathrm{ml}$ glass tubes; the reaction was initiated by adding $30 \mu \mathrm{ATCHI}(0.075 \mathrm{M})$, and absorbance was recorded for 10 min at $420 \mathrm{~nm}$ wavelength. In case of treatments a volume of the buffer solution was replaced with the volume of oil solution ( 2 oil: 3 ethanol) required for the intended concentration and tubes were incubated for $5 \mathrm{~min}$ before adding the substrate; absorbance was recorded for $10 \mathrm{~min}$ and percentage inhibition (I\%) was calculated according to the formula:

$1 \%=[(\Delta \mathrm{C}-\Delta \mathrm{T}) / \Delta \mathrm{C}] \times 100$, where $\Delta \mathrm{C}$ is the change in control absorbance/min and $\Delta \mathrm{T}$ is the change in treatment absorbance/ min. Two blanks were used, one for the control samples and one for the treatment samples; three replicates were used in each treatment. 


\section{Statistical analysis} (1971).

Median lethal $\left(L_{50}\right)$ and inhibition $\left(I_{50}\right)$ concentration values were estimated according to Finney

\section{Results and Discussion}

\section{Chemical composition of essential oils}

The major compounds in $M$. longifolia and $L$. dentata essential oils are presented in Table $1 . M$. longifolia oil contained pulegone, 1,8-cineole, I-menthone, and eucarvone as major constituents (74.95, 7.35, 6.62 and $2.68 \%$, respectively). The Pakistani $M$. Iongifolia species contained piperitenone oxide, piperitenone, germacrine D and beta-caryophyllene as major compounds (Hussain et al., 2010); $M$. longifolia species grown in Belgrade showed trans-dihydrocarvone, piperitone, cis-dihydrocarvone, neoisodihydrocarvylacetate, with only one compound in Saudi species (1,8-cineole) as the major compounds (Džamić et al., 2010). Iranian M. longifolia species contained piperitenon (43.9\%), tripal $(14.3 \%)$ and oxathiane (9.3\%) as major constituents (Khani \& Asghari, 2012). Singh et al. (2008) identified piperitenone oxide, trans-piperitone oxide and cis-piperitenone oxide as the main constituents of M. longifolia grown in Himachal, India. On the other hand, main compounds in Tunisian species were very close to Saudi species, pulegone, isomenthone and 1,8-cineole (Mkaddem et al., 2009). Also main compounds in South Africa species were similar to those of Saudi species: pulegone, menthone, and 1,8cineole (Asekun et al., 2007).

Table 1. Main compounds in Saudi Mentha longifolia and Lavandula dentata essential oils

\begin{tabular}{llllll}
\hline M. Iongifolia oil & & & L. dentata oil & \\
\hline Compound & $\mathrm{R}_{\mathrm{T}}{ }^{\mathrm{a}}$ & $\%$ & Compound & $\mathrm{R}_{\mathrm{T}}{ }^{\mathrm{a}}$ & \\
\hline Sabinene & 11.7 & 0.42 & Limonene & 15.00 & 0.33 \\
Beta-pinene & 11.78 & 0.13 & Ortho-Cymene & 16.01 & 0.19 \\
Gama-terpinene & 13.44 & 0.55 & Linalooloxide & 19.23 & 0.31 \\
Limonene & 14.98 & 0.30 & Linalool & 21.62 & 1.52 \\
1,8-cineole & 16.2 & 7.35 & Fenchone & 22.35 & 24.3 \\
L- Menthone & 26.87 & 6.62 & Fenchol & 22.63 & 2.15 \\
Borneol & 27.03 & 0.51 & Camphor & 27.60 & 61.43 \\
P-Menthone & 27.68 & 0.63 & P-Cymene-8-Ol & 30.40 & 0.31 \\
Cis -isopulegone & 29.51 & 1.10 & Myrtenol & 31.19 & 0.79 \\
Pulegone & 34.69 & 74.95 & Verbenone & 32.84 & 0.32 \\
Piperitone & 35.53 & 0.15 & Carvone & 34.95 & 0.18 \\
Trans-caryophyllene & 40.69 & 0.61 & Trans-Caryophyllene & 40.61 & 0.30 \\
Eucarvone & 42.73 & 2.68 & Beta-Selinene & 45.71 & 0.19 \\
Alpha-caryophyllene & 43.67 & 0.17 & Beta-Bisaboline & 46.29 & 0.20 \\
Germacrine D & 45.39 & 0.2 & Allo-Ocimene & 47.13 & 0.46 \\
\hline R : retention & & & & & \\
\end{tabular}

${ }^{\mathrm{a}} \mathrm{R}_{\mathrm{T}}$ : retention time.

The main compounds identified in $L$. dentata oil were camphor, fenchone and fenchol $(61.43,24.3$ and $2.15 \%$, respectively). Tunisian species (Touati et al. 2011) showed 1,8-cineole, camphor, and 
fenchone as major compounds in agreement with the present results. In contrast, main components in Moroccan species were alpha-pinene, beta-pinene, 1,8-cineole and pincarveol (Imelouane et al., 2010), while Algerian species contained 1,8-cineole, beta-pinene, trans-pinocarveol, linalool and myrtenol (Dob et al., 2005; Bousmaha et al., 2006). The qualitative and quantitative variations among the constituents of the same plant species, grown in different environments, necessitate the evaluation of biological activity of these oils individually.

\section{Fumigant toxicity}

Table 2 presents the results of fumigant toxicity. M. longifolia oil was highly toxic to test insect; this oil showed $\mathrm{LC}_{50}$ of $4.43 \mu \mathrm{l} / \mathrm{L}$ (Table 2). L. dentata oil was also highly toxic and showed $\mathrm{LC}_{50}$ of $7.92 \mu \mathrm{l} / \mathrm{L}$, which means $M$. longifolia oil was two times more toxic than $L$. dentata oil. A significant difference was found between the $L_{50}$ values of the two oils (Table 2). $L C_{50}$ value of 3.62 and $2.05 \mu \mathrm{l} / \mathrm{L}$ (which is very close to that obtained from present study) was reported for essential oil isolated from Iranian M. longifolia (Gavadi-Elmi et al., 2007; Khani \& Asghari, 2012). Other plant essential oils have been tested against $C$. maculatus and found effective. Pulegone was the major component in Mentha pulegium essential oil, 88.05\% (Aziz \& Abbass, 2010); the insecticidal activity of this oil against C. maculatus was attributed to its constituents, which confirm the results of the present work. Ziziphora clinopodioides (Boiss) essential oil had $\mathrm{LC}_{50}$ value of $4.01 \mu \mathrm{l} / \mathrm{L}$; the main compounds in this oil were similar to those of $M$. longifolia oil, pulegone, iso-menthone and 1,8-cineole (Lolestani \& Shayesteh, 2009). The second major component in M. longifolia oil, 1,8-cineole, showed high fumigant toxicity against $C$. maculatus, with $\mathrm{LC}_{50}$ value of 0.28 $\mu \mathrm{l} / \mathrm{L}$ (Aggarwal et al., 2001). Also essential oils with main components similar to those of $L$. dentata have been found effective against $C$. maculatus; essential oil from Artemisia sieberi Besser ( $54.7 \%$ camphor) showed LC $\mathrm{LC}_{50}$ value of $1.45 \mu \mathrm{l} / \mathrm{L}$ (Negahban et al., 2007). Essential oil of Artemisia haussknechtii, with camphor as main component, was found very effective against C. maculatus (Hashemi \& Safavi, 2012).

Table 2. Probit analysis for test oils toxicity to $C$. maculatus and their inhibition to ACHE activity

\begin{tabular}{lcccccc}
\hline & \multicolumn{4}{c}{ Oil Toxicity } & & \multicolumn{2}{c}{ ACHE Inhibition } \\
\cline { 2 - 6 } Oil & $\mathrm{LC}_{50}{ }^{*}(95 \% \mathrm{FL})$ & $\mathrm{LC} 95(95 \% \mathrm{FL})$ & Slope $\pm \mathrm{SE}$ & $\mathrm{I}_{50}{ }^{* *}(95 \% \mathrm{FL})$ & $\mathrm{I}_{95}(95 \% \mathrm{FL})$ & Slope $\pm \mathrm{SE}$ \\
\hline M. longifolia & $4.43^{\mathrm{a}}(4.27-4.60)$ & $6.69(6.2-7.22)$ & $1.37 \pm 0.077$ & $1.007^{\mathrm{a}}(0.647-1.41)$ & $15.9(7.39-47.7)$ & $1.37 \pm 0.077$ \\
& & & & & & \\
L. dentata & $7.92^{\mathrm{b}}(7.31-8.57)$ & $111.3(43.3-297.8)$ & $5.38 \pm 0.22$ & $9.74^{\mathrm{b}}(7.84-12.1)$ & $111.3(43.3-297.8)$ & $1.56 \pm 0.0 .09$
\end{tabular}

${ }^{*} \mathrm{LC}_{50}=\mu \mathrm{l} / \mathrm{L}$

$\left.{ }^{* *}\right|_{50}=\mu \mathrm{l} / \mathrm{ml}$

Within a column, values followed by the different letters are significantly different according to Litchfield and Wilcoxin (1949).

\section{Antiacetylcholinesterase activity}

The results of antiacetylcholinesterase activity are shown in Table 2. M. Iongifolia oil was more active than $L$. dentata oil. These two oils showed $I_{50}$ values of 1.007 and $9.74 \mu \mathrm{l} / \mathrm{ml}$, respectively, and a significant difference was found between the two $I_{50}$ values (Table 2). This result could explain, in part, the higher toxicity of $M$. longifolia oil.

The main components in $M$. longifolia oil, pulegone and 1,8-cineole, were found to be potent inhibitors to ACHE activity in insects (Houghton et al., 2006; Picallo et al., 2008; Keane \& Ryane, 1999); this could explain the inhibitory effect of $M$. longifolia oil to ACHE activity in the present study. Fenchone and camphor, the main principles in L. dentata oil were proved as inhibitors of ACHE activity in many insect species (Lopez \& Pascual-Villalobs, 2010). Also, Abdelgaleil et al. (2009) reported on the potent ACHE inhibitory effect of 1,8-cineole and fenchone. In the present study, as well as in many previous studies, the inhibitory effect of essential oils on ACHE activity and the correlation between the degree of 
enzyme inhibition and the oil toxicity (M. longifolia oil compared to L. dentata oil) indicate that ACHE is a main target for essential oils; however, Kostyukovsky et al. (2002) found that essential oils bind to both $\mathrm{ACHE}$ and octopamine receptors in insects and proposed the second target as the main target side for essential oils; the work of Enan (2001, 2005a,b) supports that of Kostyukovsky et al. (2002). The presence of an octopamine receptor in insects as a target site gives essential oils a great advantage for being more toxic to insects than to mammals.

\section{Conclusion}

Essential oils have been proved to be safe to mammals and effective alternatives to conventional pesticides (Esman, 2002); moreover, eugenol was found to be 1500 and 15000 times less toxic to rainbow trout (Oncorhynchus mykiss) than pyrethrum and azinophosmethyl, respectively (Stroh et al., 1998). Residue problems are not associated with essential oils because they are non-persistent in soils (Misra \& Pavlostathis, 1997). Some of essential oils are beneficial to human health (Huang et al., 1994). We think that development of resistance to these materials would be difficult and requires long time compared with synthetic pesticides since oils blend results in a synergistic effect (Enan, 2001) and due to presence of more than one target site (Lopez \& Pascual-Villalobs, 2010; Kostyukovsky et al., 2002; Enan, 2001). In contrast to conventional pesticides, many oils have pleasant odors. Many oils are effective against different kinds of pests (Hafedh et al., 2010; Imelouane et al., 2009; Odeyemi et al., 2008; Hussein, 2005). In spite of the many advantages mentioned above for essential oils, some components of these oils, pulegone for example, have resulted in bad side effects in animals (Gordon et al., 1987; Zhou et al., 2044). On conclusion, we think that the variability of main components among essential oils isolated from same plant species, grown in different environments, could be considered as an advantage since it provides many alternatives when resistance develops to one of these oils. More studies are needed to find new formulations to prolong the duration of the essential oils activity and expand their uses in the area of pest control.

\section{Acknowledgement}

This work was supported by King Saud University, Deanship of Scientific Research, College of Food and Agriculture Sciences Research Center.

\section{References}

Abdelgaleil, S. A. M., M. I. E. Mohamed, M. E. I. Badawy, \& S. A. A. El-arami, 2009. Fumigant and contact toxicities of monoterpenes to Sitophilus oryzae (L.) and Tribolium castaneum (Herbst) and their inhibitory effects on acetylcholinesterase activity. Journal of Chemical Ecology, 35: 518-525.

Aggarwal, K. K., A. K. Tripathi, V. Prajapati \& S. Kumar, 2001. Toxicity of 1,8-cineole towards three species of stored product coleopterans. Insect Science and its Application, 21:155-160.

Al-Rajhi, D., A. M. Al-Ahmed, H. I. Hussein \& S. M. Kheir, 2003. Acaricidal effects of cardiac glycosides, azadirachtin and neem oil against the camel tick, Hyalomma dromedarii (Acari: Ixodidae). Pest Management Science, 59: 1250-1254.

Al-Sarar, A. S., H. I. Hussein, Y. Abobakr \& A. E. Bayoumi, 2012. Molluscicidal Activity of Methomyl and Cardenolide Extracts from Calotropis Procera and Adenium arabicum against Monacha cantiana. Molecules, 17: 5310-5318.

Asekun, O. T., D. S. Grierson \& A. J. Afolayan, 2007. Effects of drying methods on the quality and quantity of the essential oil of Mentha longifolia L. subsp. Capensis. Food Chemistry, 101: 995-998.

Aziz, E. E. \& M. H. Abbass, 2010. Chemical composition and efficacy of five essential oils against the pulse beetle Callosobruchus maculatus (F.) on vigna radiate seeds. American-Eurasian Journal of Agricultural \& Environmental Science 8:411-419.

Bousmaha, L., J. B. Boti, F. A. Bekkara, V. Castola \& J. Casanova, 2006. Infraspecific chemical variability of the essential oil of Lavandula dentata L. from Algeria. Flavour and Fragrance Journal, 21: 368-372.

Casswell, G. H., 1981. Damage to stored cowpeas in the Northern part of Nigeria. Samaru, Journal of Agricultural Research, 1:154-158. 
Dob, T., D. Dahmane \& C. Chelghoum, 2005. Chemical composition of the essential oil of Lavandula dentata L. from Algeria. International Journal of Aromatherapy, 15: 110-114.

Dongre, T. K., S. E. Pawar \& M. R. Harwalker, 1993. Resistance to Callosobruchus maculates (F.) (Coleoptera:Bruchidae) in pigeon pea (Cajanus cajan (L.) Milllsp.) and other Cajanus species. Journal of Stored Products Research, 29: 319-322.

Džamić, A. M., M. D. Soković, M. S. Ristić, M. Novaković, S. Grujić-Jovanović, V. Tešević \& P. D. Marin, 2010. Antifungal and antioxidant activity of Mentha longifolia (L.) Hudson (Lamiaceae) essential oil. Botanica Serbica, 34: 57-61.

Ellman, G. L., K. D. Courtney \& R. M. Featherstone, 1961. A new and rapid colorimetric determination of acetylcholinesterase activity. Biochemical Pharmacology, 7: 88-95.

Enan, E., 2001. Insecticidal activity of essential oils: octopaminergic sites of action. Comparative Biochemistry and Physiology Part C: Toxicology \& Pharmacology 130: 325-37.

Enan, E. E., 2005a. Molecular and pharmacological analysis of an octopamine receptor from American cockroach and fruit fly in response to plant essential oils. Archives of Insect Biochemistry and Physiology, 59: 161-171.

Enan, E. E., 2005b. Molecular response of Drosophila melanogaster tyramine receptor cascade to plant essential oils. Insect Biochemistry and Molecular Biology, 35: 309-321.

Finney, D.N., 1971. Probit Analysis, $3^{\text {rd }}$ Edition. Cambridge Univ. Press, London, 318 pp.

Gavadi-Elmi, M., J. Karami \& A. R. Bandani, 2007. Fumigant toxicity of three plant essential oils on the adults of Callosobruchus maculatus (Col: Bruchidae) in vitro. New Findings in Agriculture, 2: 71-78.

Gordon, W. P., A. C. Huitric, C. L. Seth, , R. H. McClanahan \& S. D. Nelson, 1987. The metabolism of the abortifacient terpene, (R)-(+)-pulegone, to a proximate toxin, menthofuran. Drug Metabolism and Disposition 15 (5): 589-594.

Hafedh, H., B. A. Fethi, S. Mejdi, N. Emira \& B. Amina, 2010. Effect of Mentha longifolia L. ssp longifolia essential oil on the morphology of four pathogenic bacteria visualized by atomic force microscopy. African Journal of Microbiology, 4: 1122-1127.

Hashemi, S. M., \& S. A. Safavi, 2012. Control of three stored-product beetles with Artemisia haussknechtii (Boiss) (Asteraceae) essential oil. Ecologia Balkanica, 4:85-92.

Houghton, P. J., Y. Ren \& M. J. Howes, 2006. Acetylcholinesterase inhibitors from plants and fungi. Natural Product Reports, 23: 181-199.

Huang, M. T., T. Ferrarol \& C. T. Ho, 1994. Cancer chemoprevention by phytochemicals in fruits and vegetables: An overview. American Chemical Society Symposium Series, 546: 2-16.

Hussain, A. I., F. Anwar, P. S. Nigam, M. Ashraf \& A. H. Gilani, 2010. Seasonal variation in content, chemical composition and antimicrobial and cytotoxic activities of essential oils from four Mentha species. Journal of the Science of Food and Agriculture, 90: 1827-36.

Hussein, H. I., 2005. Composition of essential oils isolated from three plant species and their molluscicidal activity against Theba pisana snails. Journal of Pest Control and Environmental Science, 13: 15-24.

Hussein, H. I., A. Kamel, M. Abou-Zeid, A. H. El-Sebae \& M. A. Saleh, 1994. Uscharin, the most potent molluscicidal compound tested against land snails. Journal of Chemical Ecology, 20: 135-140.

Hussein, H. I., D. Al-Rajhi, F. El-Shahawy and S. Hashem, 1999. Molluscicidal activity of Pergularia tomentosa (L), methomyl and methiocarb, against land snails. International Journal of Pest Management, 45: 211-213.

Imelouane, B., A. El Bachiri, W. Jean-Paul, D. Jacques \& H. Amhamdi, 2010. Chemical composition, cytotoxic and antioxidant activity of the essential oil of Lavandula dentata. World Journal of Chemistry, 5: 103-110.

Imelouane, B., A. Elbachiri, M. Ankit, H. Benzaid \& K. Khedid, 2009. Physico-Chemical Compositions and Antimicrobial Activity of Essential Oil of Eastern Moroccan Lavandula dentata. International Journal of Agriculture and Biology, 11: 113-118.

Isman, M. B., 2000. Plant essential oils for pest and disease management. Crop Protection, 19: 603-608.

Khani, A. \& J. Asghari, 2012. Insecticide activity of essential oils of Mentha longifolia, Pulicaria gnaphalodes and Achillea wilhelmsii against two stored product pests, the flour beetle, Tribolium castaneum, and the cowpea weevil,Callosobruchus maculatus. Journal of Insect Science, 12:73 available online: insectscience.org/12.73. 
Koliopoulos, G., D. Pitarokili, E. Kioulos, A. Michaelakis \& O. Tzakou, 2010. Chemical composition and larvicidal evaluation of Mentha, Salvia, and Melissa essential oils against the West Nile virus mosquito Culex pipiens. Parasitology Research, 107: 327-335.

Kostyukovsky, M., A. Rafaeli, C. Gileadi, N. Demchenko \& E. Shaaya, 2002. Activation of octopaminergic receptors by essential oil constituents isolated from aromatic plants: possible mode of action against insect pests. Pest Management Science, 58:1101-1106.

Litchfield, J. T. \& F. A. Wilcoxin, 1949. Simplified method of evaluating dose-effect experiments. Journal of Pharmacology and Experimental Therapeutics, 96: 99-103.

Lolestani, F. A. \& N. Shayesteh, 2009. Fumigant Toxicity of Ziziphora clinopodioides (Boiss.) (Lamiaceae) Against Adults and Eggs of Callosobruchus maculatus (Fab.) (Coleoptera: Bruchidae). Journal of Biological Sciences, 9: $92-95$.

López, M. D. \& M. J. Pascual-Villalobos, 2010. Mode of inhibition of acetylcholinesterase by monoterpenoids and implications for pest control. Industrial Crops and Products, 3: 284-288.

Misra, G. \& S. G. Pavlostathis, 1997. Biodegradation kinetics of monoterpenes in liquid and soil-slurry systems. Applied Microbiology and Biotechnology, 47: 572-577.

Mkaddem, M., J. Bouajila, M. Ennajar, A. Lebrihi, F. Mathieu \& M. Romdhane, 2009. Chemical composition and antimicrobial and antioxidant activities of Mentha longifolia (L. and viridis) essential oils. Journal of Food Science, 74: 358-63.

Mossa, J. S., M. A. Al-Yahya \& I. A. Al-Meshal, 2000. Medicinal Plants of Saudi Arabia, King Saud University Press, Riyadh,

Negahban, M., S. Moharramipour and F. Sefidkon, 2007. Fumigant toxicity of essential oil from Artemisia sieberi Besser against three stored-product insects. Journal of Stored Products Research, 43: 123-128.

Odeyemi, O. O., P. Masika \& A. J. Afolayan, 2008. Insecticidal activities of essential oil from the leaves of Mentha longifolia L. subsp. capensis against Sitophilus zeamais (Motschulsky) (Coleoptera: Curculionidae). African Entomology, 16: 220-225.

Orhan, I., S. Aslan, M. Kartal, B. Şener \& K. H. C. Baser, 2008. Inhibitory effect of Turkish Rosmarinus officinalis L. on acetylcholinesterase and butyrylcholinesterase enzymes. Food Chemistry, 108: 663-668.

Picollo, M. I., A. C. Toloza, C. G.Mougabure, J. Zygadlo \& E. Zerba 2008. Anticholinesterase and pediculicidal activities of monoterpenoids. Fitoterapia, 79: 271-8.

Ross, J. D. \& C. Sombrero, 1991. Environmental control of essential oil production in Mediterranean plants, In: Harbone, J. B. \& F. A. Tomas-Barbera (Eds.), Ecological chemistry and biochemistry of plant terpenoids. Clarendon Press, Oxford, pp: 83-94.

Şenol, F. S., I. Orhan, F. Celep, A. Kahraman, M. Doğan, G. Yilmaz \& B. Şener, 2010. Survey of 55 Turkish Salvia taxa for their acetylcholinesterase inhibitory and antioxidant activities. Food Chemistry, 120: 34-43.

Singh, H. P., D. R. Batish, S. Mittal, K. S. Dogra, S. Yadav \& R. K. Kohli, 2008. Constituents of Leaf Essential Oil of Mentha longifolia from India. Chemistry of Natural Compounds, 44: 528-529.

Stroh, J., M. T. Wan, M. B. Isman \& D. J. Moul, 1998. Evaluation of the acute toxicity to juvenile Pacific Coho salmon and rainbow trout of some plant essential oils, a formulated Product, and the carrier. Bulletin of Environmental Contamination and Toxicology, 60: 923-930.

Touati, B., H. Chograni, I. Hassen, M. Boussaid, L. Toumi \& N. Ben Brahim, 2011. Chemical composition of the leaf and flower essential oils of Tunisian Lavandula dentata L. (Lamiaceae). Chemistry \& Biodiversity, 8: 15601568.

Zhou, S., H. Koh, Y. Gao, Z. Gong, E. Lee, 2004. Herbal bioactivation: The good, the bad and the ugly. Life Sciences, 74:935-968. 